\title{
Determination of Proximate Composition and Amino Acid Profile of Jackfruit Seed and Utilization of Its Seed Flour for Development of Protein Enriched Supplementary Food
}

\author{
Abida Sultana ${ }^{1}$, Mohammad Nurul Amin², Muhammed Yusuf Miah ${ }^{1, ~ *, ~ A s h i s h ~ K u m a r ~ S a r k e r ~}{ }^{3}$, \\ Md. Mahabub Alam Rasel ${ }^{4}$, Mohammad Tarek Aziz $^{5}$, Farzana Sharmin ${ }^{2}$, Md. Abdul Hakim², \\ Hosneara Shiddika ${ }^{2}$, Shajal Hossain Emon ${ }^{2}$, Tanjina Parvin Tuli ${ }^{2}$, Mst Monira Khanom ${ }^{2}$ \\ ${ }^{1}$ Department of Applied Chemistry and Chemical Engeering, Noakhali Science and Technology University, Noakhali, Bangladesh \\ ${ }^{2}$ Department of Pharmacy, Atish Dipankar University of Science and Technology, Dhaka, Bangladesh \\ ${ }^{3}$ Institute of Food Science and Technology, Bangladesh Council of Scientific and Industrial Research (BCSIR), Dhaka, Bangladesh \\ ${ }^{4}$ Department of Applied Nutrition and Food Technology, Islamic University, Kushtia, Bangladesh \\ ${ }^{5}$ Department of Pharmacy, State University of Bangladesh, Dhaka, Bangladesh
}

Email address:

yuri19742003@yahoo.com (M. Y. Miah)

${ }^{*}$ Corresponding author

To cite this article:

Abida Sultana, Mohammad Nurul Amin, Muhammed Yusuf Miah, Ashish Kumar Sarker, Md. Mahabub Alam Rasel, Mohammad Tarek Aziz, Farzana Sharmin, Md. Abdul Hakim, Hosneara Shiddika, Shajal Hossain Emon, Tanjina Parvin Tuli, Mst Monira Khanom. Determination of Proximate Composition and Amino Acid Profile of Jackfruit Seed and Utilization of Its Seed Flour for Development of Protein Enriched Supplementary Food. Cell Biology. Vol. 5, No. 6, 2017, pp. 57-65. doi: 10.11648/j.cb.20170506.11

Received: August 12, 2017; Accepted: September 5, 2017; Published: November 28, 2017

\begin{abstract}
The research focused on utilization of jackfruit seed (JFS) flour with higher nutritional worth to develop a protein enriched supplementary food. The nutritional analysis of JFS flour revealed that, it contains $39.02 \%, 16.01 \%, 0.98 \%, 3.56 \%$, $1.30 \%, 42.49 \%$ moisture, crude protein, crude fat, crude fiber, ash and carbohydrate respectively. In JFS flour, amount of potassium $(705.71 \mathrm{mg} / 100 \mathrm{gm})$, calcium $(115.85 \mathrm{mg} / 100 \mathrm{gm})$ and magnesium $(96.75 \mathrm{mg} / 100 \mathrm{gm})$ were in higher quantity than other minerals. Proteins were isolated from JFS flour for its amino acid analysis. Highest Proteins extraction rate (89.94\%) was found at $\mathrm{pH}-10$ and isoelectric point for protein precipitation was found at $\mathrm{pH}-1.63$. In the isolated protein the essential amino acids were Lysin (10.30\%), Isoleucine (8.61\%), Leucine (6.73\%), Methionine (4.82\%), Threonine (3.90\%), Valine (1.73\%), Histidine (1.92\%), and non-essential amino acids were Aspertic acid (4.40\%), Tyrosine (6.67\%), Glutamic acid (4.34\%), Glycine (4.94\%), Arginine (2.44\%), Serine (4.46\%). In the study a protein supplementary food product, cake, was prepared by blending JFS flour with wheat flour. six sets of cakes were prepared at a ratio of 50(WC), 40:10(WJC1), 30:20(WJC2), 25:25(WJC3), 20:30(WJC4), 15:35(WJC5) by mixing wheat flour and JFS flour respectively. From proximate composition analysis and sensory evaluation of prepared cakes, WJC3 was found to contain a higher amount of protein, $13.50 \%$ and greater acceptability. Microbiological analysis showed that in WJC3 the presence of microorganisms (Total Viable Count, Coli form and Yeast \&Mould) was within the range for safety indication of bakery products. So, the protein supplementary food using JFS flour is completely safe to eat without using any preservatives.
\end{abstract}

Keywords: Jackfruit Seed, Protein, Supplementary Food, Microbiological Analysis

\section{Introduction}

In public perception, importance of Food Science and Nutrition is very high in the modern world. Lack of nutrition is increasing rapidly day by day specially in developing countries like Bangladesh. As a result, development of 'nutritional value added foods' is essential. Jackfruit is the most popular tropical fruit with high nutritional value. It is 
the largest edible fruit in earth [1,2]. Jackfruit pulp is eaten fresh and used in fruit salads [3]. But jackfruit seeds are less popular as vegetable and are eaten when boiled or roasted. These are believed to be digested with difficulty [4]. The nutrient composition of jackfruit seed is similar to that of grains $[5,6]$. The seeds are rich source of carbohydrates and proteins and good source of fiber and vitamins [7].

Among the nutrients, protein plays a significant role in human body. Next to water, protein is the major component of body tissues. It is the essential nutrient for growth. In the human body, proteins are broken down into amino acids which are used as precursors to nucleic acids, co-enzymes, hormones, immune response, cellular repair, and other molecules essential for life. Jackfruit seed protein contains both essential and non-essential amino acids which impart their specific function $[8,9]$.

This major nutrient source is wasted every year because people think that fresh seeds cannot be kept for a long time [7]. But flour of jackfruit seed can be stored for a long period and utilized for varied applications [10]. In developing countries, malnutrition is caused due to inadequate consumption of protein. To minimize this malnutrition, exploration and evaluation of non-conventional cheap protein sources is important [11]. The utilization of jackfruit seeds as protein-rich supplementary food source could be one of the best solutions in this regard. It could be used in balanced diets and functional foods without any concern for health risk [12]. The jackfruit seed may be blended with wheat flour to explore a low cost alternative raw material for bakery and confectionary products [13].

A Protein supplementary food is the food that provides protein which may not be consumed in sufficient quantities. Cake is a common and popular food among people especially to children. So, it is a convenient food on the way to protein supplementation. Incorporation of jackfruit seed flour in the preparation of cake will bring new taste and flavor. But taste, color and aroma is not enough for the acceptability of a food to people. Besides these, microbial quality is the most important characteristics of a food to be safe to eat. Lectins, the carbohydrate binding proteins of jackfruit seeds, have potential antimicrobial activities [14]. So, preparation of cake by mixing jackfruit seed flour and wheat flour may be safe microbiologically without using any preservatives.

In this study, our aim was to determine the nutritional and mineral composition of jackfruit seeds and amino acid composition of its isolated protein. We wanted to develop a protein enriched supplementary food, to observe its nutrition value and susceptibility towards microbial attack.

\section{Materials and Methods}

\subsection{Preparation of Jackfruit Seed Flour}

Jackfruit seeds were bought from local market of Dhaka, Bangladesh. The brown coats of seeds were peeled off and then sliced into small pieces. Then they were dried in hot box oven at $55^{\circ} \mathrm{C}$ for three days. The seeds were formed into fine powder by using a commercial blender. Then the jackfruit seed (JFS) flour were stored in refrigerator $\left(\right.$ at $\left.4{ }^{\circ} \mathrm{C}\right)$ until they were used for analysis [15].

\subsection{Proximate Composition Analysis of Jackfruit Seed Flour}

Proximate analysis of any food sample involves analysis of its total moisture content, crude ash, crude protein, crude fat, crude fiber, total carbohydrate, and total energy value.

\subsubsection{Total Moisture Content Analysis}

Total moisture content of JFS flour was determined according to the procedure described in AACC (2000) method No. 44-15A as mentioned by Ileleji et al. [16]. The pre-weighted JFS flour sample was placed in a pre-weighted china dish and dried in hot box oven with fan at $105^{\circ} \mathrm{C}$ for $4-$ 5 hours for removing total moisture of sample. Then total moisture content was determined as follows:Moisture $(\%)=$ [ $\{$ Wt. of original sample $-\mathrm{Wt}$. of dried sample $) / \mathrm{Wt}$. of original sample $\} \times 100]$

\subsubsection{Crude Protein Analysis}

The powdered JFS flour sample was tested for crude protein content according to the Kjeldahl's method as reported by JM Lynch et al. [17] which involved protein digestion and distillation. In digestion stage, $2.0 \mathrm{~g}$ JFS flour was digested by $15-20 \mathrm{ml}$ of $98 \%$ sulfuric acid in a $250 \mathrm{ml}$ Kjeldhal flask, $1 \mathrm{~g}$ of digestion mixture added to act as catalyst. The resulting mixture was subjected to heat in the digestion chamber until it become transparent followed by normal cooling. The cooled digest was transferred into a 100 ml volumetric flask and made up to the mark with distilled water. In a Markham distillation apparatus $5.0 \mathrm{ml}$ digest was taken via a small funnel aperture. This funnel and the inner surface of the apparatus were washed with sufficient amount of distilled water followed by the addition of 3-4 drops of phenolphthalein and $5 \mathrm{ml}$ of $40 \%(\mathrm{~W} / \mathrm{V}) \mathrm{NaOH}$ solution. In a $100 \mathrm{ml}$ conical flask $5 \mathrm{ml}$ of $2 \%$ boric acid and 1 or 2 drops of mixed indicator was taken and placed under the condenser such that the condenser tip was under the liquid. The digest in the condenser was steamed through until enough ammonium sulfate was collected. The Boric acid with indicator solution changed color from red to green showing that all the ammonia liberated had been trapped. The solution in the receiving flask was titrated against $0.063 \mathrm{~N}$ hydrochloric aciduntil the appearance of purple color. Also, a blank was run through along with the sample. After titration, the $\%$ nitrogen was calculated using the formula: $\%$ Nitrogen $=(\mathrm{Vs}-\mathrm{VB}) \times \mathrm{M}$ acid $\times 0.01401 \times 100 \mathrm{~W}$. Where, Vs $=$ Volume $(\mathrm{ml})$ of acid required to titrate sample; $\mathrm{VB}=$ Volume (ml) of acid required to titrate the blank; $\mathrm{M}$ acid= Molarity of acid; $\mathrm{W}=$ Weight of sample $(\mathrm{g})$.

\subsubsection{Ash Content Determination}

Ash is an inorganic residue remaining after the material has been completely burnt at a temperature of $550^{\circ} \mathrm{C}$. It is the aggregate of all non-volatile inorganic elements. According to AOAC Official Method 942.05 used by NJ Thiex et al. 
[18], $8 \mathrm{~g}$ of finely ground dried sample was weighed into a porcelain crucible and incinerated at $550^{\circ} \mathrm{C}$ for $6 \mathrm{hr}$ in a muffle furnace until ash was obtained. The ash was cooled in desiccators and reweighed. The $\%$ ash content in the sample was calculated as follows: Ash $(\%)=(\mathrm{Wt}$. of ash $/ \mathrm{Wt}$. of sample taken) $\times 100$

\subsubsection{Crude Fiber Determination}

Crude fiber content was determined using the method described by M Jrgen [19]. Based on AOAC Official Method 978.10 with some necessary modification. $2 \mathrm{~g}$ fat free sample of JFS flour was taken into a fiber flask and $100 \mathrm{ml}$ of 0.255 $\mathrm{N} \mathrm{H} 2 \mathrm{SO} 4$ was added. Then the mixture was heated under reflux with heating mantle for one hour followed by filtering with a fiber sieve cloth. $100 \mathrm{ml}$ of $0.313 \mathrm{M} \mathrm{NaOH}$ was added to the residue obtained and heated under reflux for another one hour. The mixture was filtered again through a fiber sieve cloth with subsequent washing with $10 \mathrm{ml}$ of acetone and $50 \mathrm{ml}$ hot water. The residue was dried in an oven overnight at $150^{\circ} \mathrm{C}$. The oven dried crucible containing the residue was cooled in a desiccators and latter weighted (W1) for ashing at $550^{\circ} \mathrm{C}$ for 4 hours. The crucible containing white and grey ash (free of carbonaceous material) was cooled in a desiccator and weighted to obtain W2. The $\%$ of crude fiber was calculated as follows-Fiber $(\%)=[\{(\mathrm{W} 1-$ W2) / Wt. of sample $\} \times 100]$.

\subsubsection{Crude Fat Analysis}

The crude fat in the powdered sample was determined using Soxhlet extraction method (AOAC Official Method 920.39) as mentioned by NJ Thiexet al. [20]. In this extraction method, fat is extracted with petroleum ether. Samples (3.0 g) weighed accurately into labeled thimble and $150 \mathrm{ml}$ of petroleum ether (boiling point $40-60^{\circ} \mathrm{C}$ ) was taken in a $250 \mathrm{ml}$ boiling flasks. The extraction thimbles were plugged tightly with cotton wool. After that, the Soxhlet apparatus was assembled and allowed to reflux for $24 \mathrm{hrs}$. The thimble was removed with care and petroleum ether collected from the top container and drained into another container for re-use. After that, the boiling flask was heated in a hot air oven until it was almost free of petroleum ether. After drying, it was cooled in desiccators and weighed.

\subsubsection{Determination of Total Carbohydrate}

The total percentage carbohydrate content in the jackfruit seed flour sample was determined by the difference method [21]. This is calculated as follows:

$$
\% \text { carbohydrate }=100-(\% \text { moisture }+\% \text { crude fiber }+\% \text { protein }+\% \text { lipid }+\% \text { ash })
$$

\subsection{Mineral Analysis of Jackfruit Seed Flour}

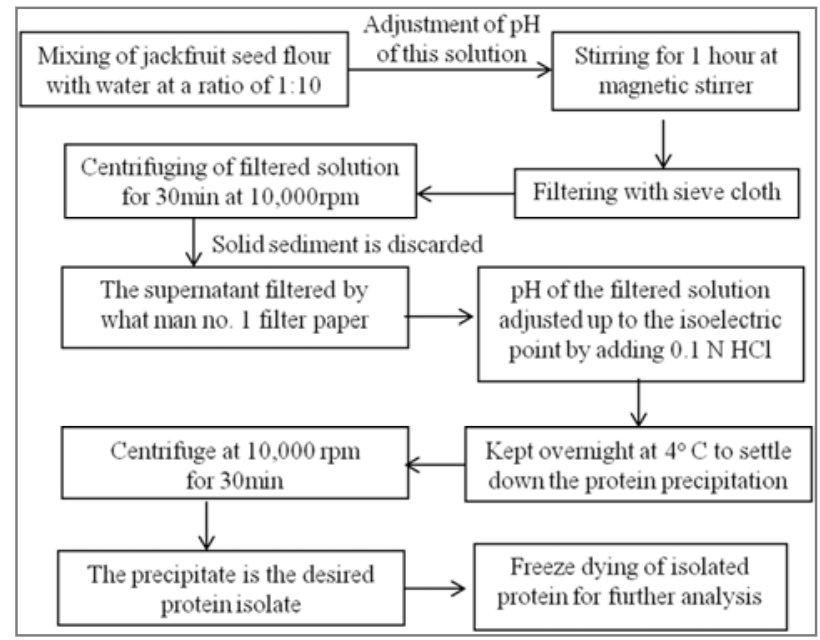

Figure 1. Flow Chart for protein isolation from jackfruit seed flour.

This method is based on ion-exchange chromatography [22]. At first, accurately weighted JFS flour sample was heated at $800^{\circ} \mathrm{C}$ for $6 \mathrm{hr}$ in a muffle furnace. Then $2 \mathrm{~mL}$ conc. HNO3 was added to the sample and heated to evaporate. Then $10 \mathrm{~mL}$ conc. HClwas added and heated for $10 \mathrm{~min}$. The sample was then filtered and volume up to 100 $\mathrm{mL}$. From the filtrate $10 \mathrm{~mL}$ was taken to dilute again in a $100 \mathrm{~mL}$ volumetric flask. The sample then analyzed by Thermo Scientific DionexIonpacTMICS-1600 column (4 x $250 \mathrm{~mm}$ ) based on ion-exchange chromatography.

\subsection{Isolation of Total Protein from Jackfruit Seed Flour}

Total protein isolation was done by "alkaline extraction and isoelectric precipitation" technique. The principle of this method is to dissolve the protein in alkaline aqueous solutions in specific $\mathrm{pH}$ at 7.0, 8.0, 10.0, 11.00 and 12.00. Then adjusted the solution $\mathrm{pH}$ with acid $(\mathrm{HCl})$ until the isoelectric point was attainedand then separated out the protein isolates [23]. The protein content was calculated after nitrogen analysis by Kjeldahl Method using the conversion factor of 6.25. The protein extraction rate was as: Extraction rate $\%=$ Total protein after extraction/ Total original JFS protein $\times 100 \%$.

\subsection{Amino Acid Analysis of Isolated Protein}

Amino acid profile of the isolated protein was determined by the help of the method described by Bao Yang et al. [24] with some modifications. Freeze dried isolated protein sample was taken and a fine paste was made by mortar and pestle using $6 \mathrm{~N} \mathrm{HCl}$ and filtered through whatman no. 1 filter paper and take it in $250 \mathrm{~mL}$ round bottom flask. The flask is then placed in a heating mantle at $1100 \mathrm{C}$ for 22 hours for hydrolysis of protein. After hydrolysis, the solution was kept in a evaporating dish to evorapate $\mathrm{HCl}$ on water bath. It was then filtered through Whatman no. 1 filter paper in a $25 \mathrm{~mL}$ volumetric flask with $0.1 \mathrm{~N} \mathrm{HCl}$. The $25 \mathrm{~mL}$ solution was kept as Stock solution. Again the stock solution filtered through $0.45 \mu \mathrm{m}$ syringe filter. Then the stock solution and standard solution were run through the amino acid analyzer. The calculation was done by using following formula: 


$$
\text { Concentration of Amino Acid }=\frac{\text { Area of Sample }}{\text { Area of Standard }} \times \text { Concentration of standard }
$$

\subsection{Analysis of Cake Prepared From Jackfruit Seed Flour}

\subsubsection{Preparation of Cake}

Six sets of cakes were prepared by blending wheat flour and jackfruit seed flour at different ratio to determine their proximate composition and then select the best cake rich in protein and other nutritional value. The amount of the ingredients used for these cake preparations are given in Table 1:

At first egg, soya bean oil, sugar and baking powder were mixed manually. Then the mixture of wheat flour and jackfruit seed flour were added in the mixture. Again mixed them thoroughly till all the ingredients give a fine slurry. Then placed it in a baking die for cake and baked for 20 minute at $180^{\circ} \mathrm{C}$ at a micro-oven. After the preparation of cake, it was packed in aluminum foil paper and stored.

Table 1. Component and their amount used in Cake preparation.

\begin{tabular}{ll}
\hline Component & Amount \\
\hline Wheat Flour: Jackfruit seed & 50:0 (WC),40:10 (WJC1),30:20 (WJC2), \\
flour & (WJ:25 (WJC3), 20:30 (WJC4), 15:35 \\
Sugar & $15 \mathrm{gm}$ \\
Egg & 2 piece \\
Edible oil & $20 \mathrm{ml}$ \\
Baking Powder & $30 \mathrm{mg}$ \\
\hline
\end{tabular}

\subsubsection{Proximate Composition Analysis of Cakes}

Proximate composition of prepared six sets of cake was done by the methods mentioned in section 2.2.

\subsubsection{Sensory Evaluation of Cake}

Sensory evaluation was done on the basis of Nine Point Hedonic Scale (Table-2) rating to determine the preference in color, flavor, taste and overall acceptability [25]. 6 sets of cake have been subjected to sensory evaluation test in order to identify the most desirable product for consumption. 6 members were chosen from the Department of Applied Chemistry and Chemical Engineering, Noakhali Science \& Technology University, Noakhali. The consumers were instructed to first evaluate each sample bysniffing alone and then by tasting. The intensity of perceived odor was rated as flavor. Consumers rinsed their mouths with water after tasting each sample.

Table 2. Hedonic 9-point scale.

\begin{tabular}{ll}
\hline Parameter & Point \\
\hline Dislike extremely & 1 \\
Dislike Very Much & 2 \\
Dislike moderately & 3 \\
Dislike Slightly & 4 \\
Neither like or dislike & 5 \\
Like slightly & 6 \\
Like moderately & 7 \\
Like Very Much & 8 \\
Like extremely & 9 \\
\hline
\end{tabular}

\subsection{Microbiological Assessment of Cake}

Bakery products are needed to be microbiologically stable and safe to eat. Three tests are mostly important to declare a product is stable microbiologically [26]. These tastes are:

Aerobic Meshophilic Count (Determination of Total Viable Count)

Pour Plate Techique (Estimation of yeast \&mould) \& Most Probable Number Method (Estimation of Coliform)

\subsubsection{Aerobic Meshophilic Count}

This method is used to indicate total viable count (TVC) for quality assessment of the cake. At first $90 \mathrm{ml}$ of diluents (Saline Water $0.85 \%$ ) was added with $10 \pm 0.1$ gm accurately weighted cake sample in a sterile blended jar and blended about 2 minutes at approximately $8000 \mathrm{rpm}$ [26, 27]. A decimal dilution was prepared by following the ratio $1: 9$ for food homogenate and diluents respectively. $1 \mathrm{ml}$ of food homogenate was pipetted into $9 \mathrm{ml}$ of diluents containing a tube. From first dilution $1 \mathrm{ml}$ was transferred into a tube containing $9 \mathrm{ml}$ diluents for second dilution. All dilutions were shaken for 25 times in $30 \mathrm{~cm}(1 \mathrm{ft})$ arc within $7 \mathrm{sec}$. Then $1 \mathrm{ml}$ of each dilution was pipetted into separate appropriately marked petri dishes. 12-15 ml Agar solution was added $\left(45 \pm 1^{\circ} \mathrm{C}\right)$ to each plate within $15 \mathrm{~min}$ of original dilution. Then it was allowed to solidify. The samples were incubated at $35^{\circ} \mathrm{C}$ for 48 hours. After incubation, all the colonies were counted as per given formula: $N=\frac{\sum \mathrm{C}}{(\mathrm{N} 1+0.1 \mathrm{~N} 2) \mathrm{D}}$

Where, $\sum \mathrm{C}=$ the sum of colonies counted on all the dishes retained; $\mathrm{N} 1=$ the no. of dishes retained in the first dilution; $\mathrm{N} 2=$ the no. of dishes retained in the second dilution; $\mathrm{D}=$ the dilution factor corresponding to first dilution [28].

\subsubsection{Pour Plate Technique (Estimation of Yeast and Molds in Cake)}

Diluted samples were prepared by the method described in section 2.7.1. Then $1 \mathrm{ml}$ of each dilution was pipetted into separately marked petri dishes. After that $10-12 \mathrm{ml}$ of acidified Poly Dextrose Agar, pH 3.5 (by 10\% tartaric acid) was added $\left(45 \pm 1^{\circ} \mathrm{C}\right)$. Diluted samples and agar medium were mixed and allowed to solidify $[29,30]$. Then they were incubated at $25^{\circ} \mathrm{C}$ for 7 days and observed everyday to mark colonies. Counted colonies were multiplied by the inverse of the corresponding dilution and resulted as yeast and mould count per gm.

\subsubsection{Most Probable Number Method for Coliform Test}

Coliform present in food is mostly determined by the Most Probable number method. Similar method was followed to prepare diluted samples as in section 2.7.1. Then each of three tubes of Lauryl Tryptose (LST) broth (containing inverted Durham tubes) was inoculated with $1 \mathrm{ml}$ of food homogenate $(1: 10,1: 100,1: 1000)$ respectively. Inoculated LST tubes were then incubated at $35 \pm 0.50 \mathrm{C}$ After 24hour, gas production was observed in the tube. Production of gas gives positive result for the presence of coliform. Absence of gas implies the negative 
results for coliform in food sample [31-33].

\section{Results and Discussion}

\subsection{Proximate Composition Analysis of Jackfruit Seed Flour}

The proximate compositions of studied Jackfruit Seed Flour are given in Table-3. Carbohydrate and moisture was found in higher amount, $42.49 \%$ and $39.22 \%$ respectively. According to our study, crude protein content in jackfruit seed flour (JFS) is 16.01\%. Awal et al. (1991) reported 5.69\% proteinin JFS which was much lower than the findings of the present work [34]. Kumar et al. (1988) found that, protein content of two varieties of JFSwas within range of $17.8-18.3 \%$ which is slightly higher than present study [35]. Content of protein varied from $13.13-18.13 \%$ among the three types of jackfruit seeds (Khaja, Gala and Durosha) from the research revealed by Abedin et al. (2012) [7]. Besides, in our study fat, fiber and ash was also found in small amount. The variations of our results with that of others may be caused due to different seed varieties, environmental condition and other geological factors.

Table 3. Proximate composition Jackfruit Seed Flour (values are mean \pm standard deviation for three replications).

\begin{tabular}{ll}
\hline Component & Amount (\%) \\
\hline Moisture Content & $39.22 \pm 0.18 \%$ \\
Crude Protein & $16.01 \pm 0.11 \%$ \\
Crude Fat & $0.98 \pm 0.02 \%$ \\
Crude Fiber & $3.56 \pm 0.14 \%$ \\
\hline
\end{tabular}

\begin{tabular}{ll}
\hline Component & Amount (\%) \\
\hline Crude Ash & $1.30 \pm 0.10 \%$ \\
Carbohydrate & $42.49 \pm 0.21 \%$ \\
\hline
\end{tabular}

\subsection{Mineral Analysis of Jackfruit Seed Flour}

Mineral contents in JFS flour were quantified by ion exchange chromatography. The chromatogram is shown in figure- 2 and the corresponding values are given in table 4 .

Table 4. Mineral Composition of jackfruit Seed Flour in mg/100gm.

\begin{tabular}{ll}
\hline Component & Amount $(\mathbf{m g} / \mathbf{1 0 0 g m})$ \\
\hline Lithium & 0.05 \\
Sodium & 38.41 \\
Ammonium & 12.33 \\
Potassium & 705.71 \\
Magnesium & 115.85 \\
Calcium & 96.75 \\
\hline
\end{tabular}

In our study, the value of potassium $(705.71 \mathrm{mg} / 100 \mathrm{gm})$, calcium (115.85 mg/100gm) and magnesium (96.75 mg/100gm) were present in much higher quantity than the other minerals. On the other hand, the value of calcium and magnesium were found within the range of $0.02-0.38$ \& 150.00-210.00 $\mathrm{mg} / 100 \mathrm{gm}$ for three varieties of seed according to the report of Abedin et al. (2012) [7]. The $\mathrm{Na} / \mathrm{K}$ ratio less than one is recommended by doctors and important for prevention of high blood pressure. In JFSflour, $\mathrm{Na} / \mathrm{K}$ ratio was found less than one (0.054). So, it is expected to reduce high blood pressure along with the other functions of its minerals [36].

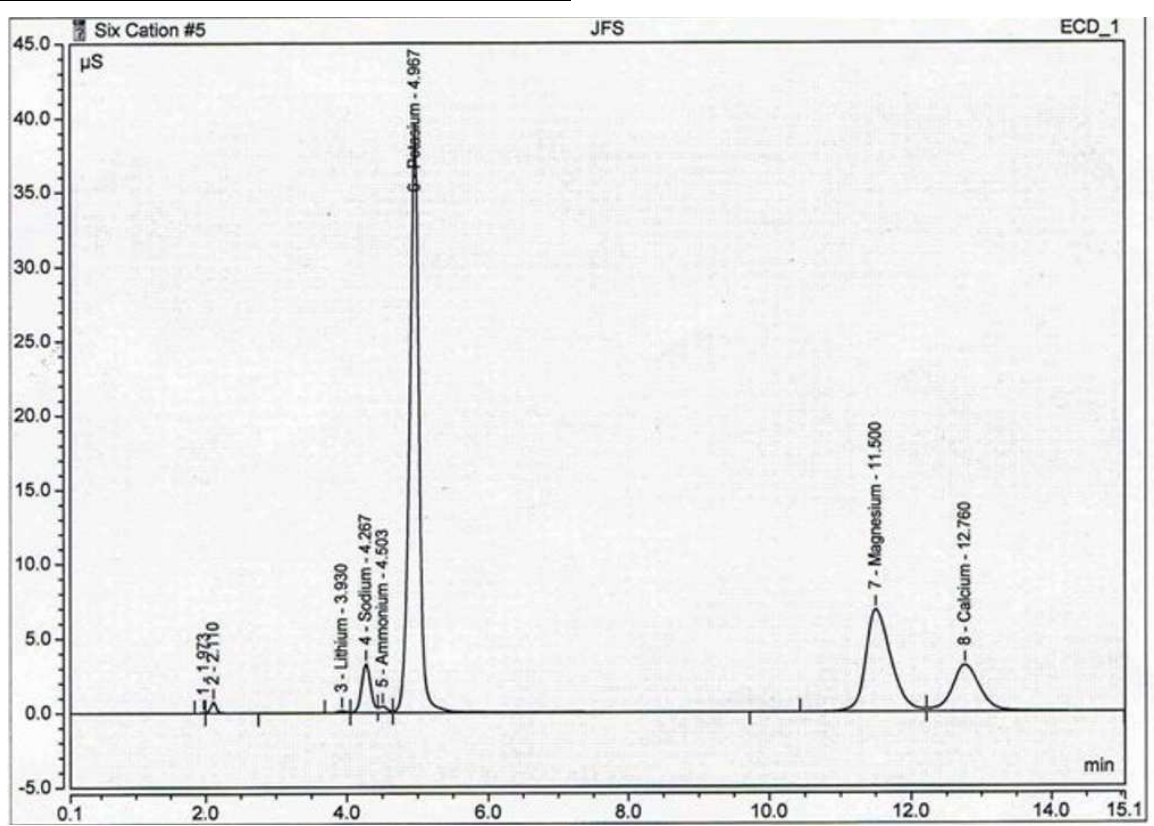

Figure 2. Chromatogram of mineral analysis of jackfruit seed flour.

\subsection{Isolation of Protein}

In alkaline condition, extraction rate of protein for food stuffs increased with the increasing of $\mathrm{pH}$ value [37, 38]. But present study shows that in case of jackfruit seed flour protein, extraction rate is highest at $\mathrm{pH}-10.00$ but after $\mathrm{pH}-10$ extraction rate decreases with increasing the $\mathrm{pH}$ value. The extraction rate is found $63.71 \%, 67.45 \%, 89.94 \%, 78.25 \%$, $75.07 \%$ for $\mathrm{pH}$ value $7.00,8.00,10.00,11.00 \& 12.00$ respectively. Denaturation of proteinat excess alkaline condition could be the probable cause of the decrease of protein extractability [39]. The isoelectric point at which the extracted protein precipitated was found $\mathrm{pH}-1.63$. 


\subsection{Amino Acid Analysis of Isolated Protein}

The protein isolated from jackfruit seed flour was analyzed to detect and determine the content of amino acid present in the protein. Seven essential and six non-essential amino acids were found in JFS protein. Table-5 shows that JFS flour protein contains highest percentage of lysine (10.30\%) and lowest percentage of valine $(1.73 \%)$. We also found that $8.61 \%, 6.73 \%, 4.82 \%, 3.90 \%$ and $1.92 \%$ of isoleucine, leucin, methionine, threonine and histidine respectively present as essential amino acid. Among the non-essential amino acid aspartic acid, arginine, glutamic acid, serine, glycine andtyrosine were found $4.80 \%, 2.44 \%, 4.34 \%$, $4.46 \%, 4.94 \%$, and $6.67 \%$ respectively.

Table 5. Contents of amino acid present in total protein of jackfruit seed flour.

\begin{tabular}{lllll}
\hline SI. No. & Essential Amino Acids & Amount (\%) & Non-essential Amino Acids \\
\hline 01. & Lysine & 10.30 & Aspartic Acid & Amount (\%) \\
02. & Isoleucine & 8.61 & Arginine & Glutamic Acid \\
03. & Leucine & 6.73 & Serine & 4.80 \\
04. & Methionine & 4.82 & Glycine & 4.46 \\
05. & Threonine & 3.90 & Tyrosine & 4.94 \\
06. & Valine & 1.73 & & 6.67 \\
07. & Histidine & 1.92 & \\
\hline
\end{tabular}

\subsection{Proximate Composition and Mineral Analysis of Cakes}

Different proportion of jackfruit seed flour and wheat flour were mixed and the proximate compositions of the blends were analyzed to select the highest nutritional value added cake. The blends of wheat flour and jackfruit seed flour used for preparing cakes were 50(WC), 40:10(WJC1), 30:20(WJC2), 25:25(WJC3), 20:30(WJC4), 15:35(WJC5) respectively. Comparative assessment of nutritional composition of cakes showed that moisture content is similar in all the cakes in which WC contain higher amount $(30.46 \%)$ and WJC1 contain lower amount $(28.15 \%)$ of moisture. The highest amount of crude protein content $(13.50 \%)$ was foundin WJC3. The other cakes WC, WJC1, WJC2, WJC4 and WJC5 contain 8.85\%, 10.05\%, 12.55\%, $12.75 \%$ and $12.65 \%$ crude protein respectively.

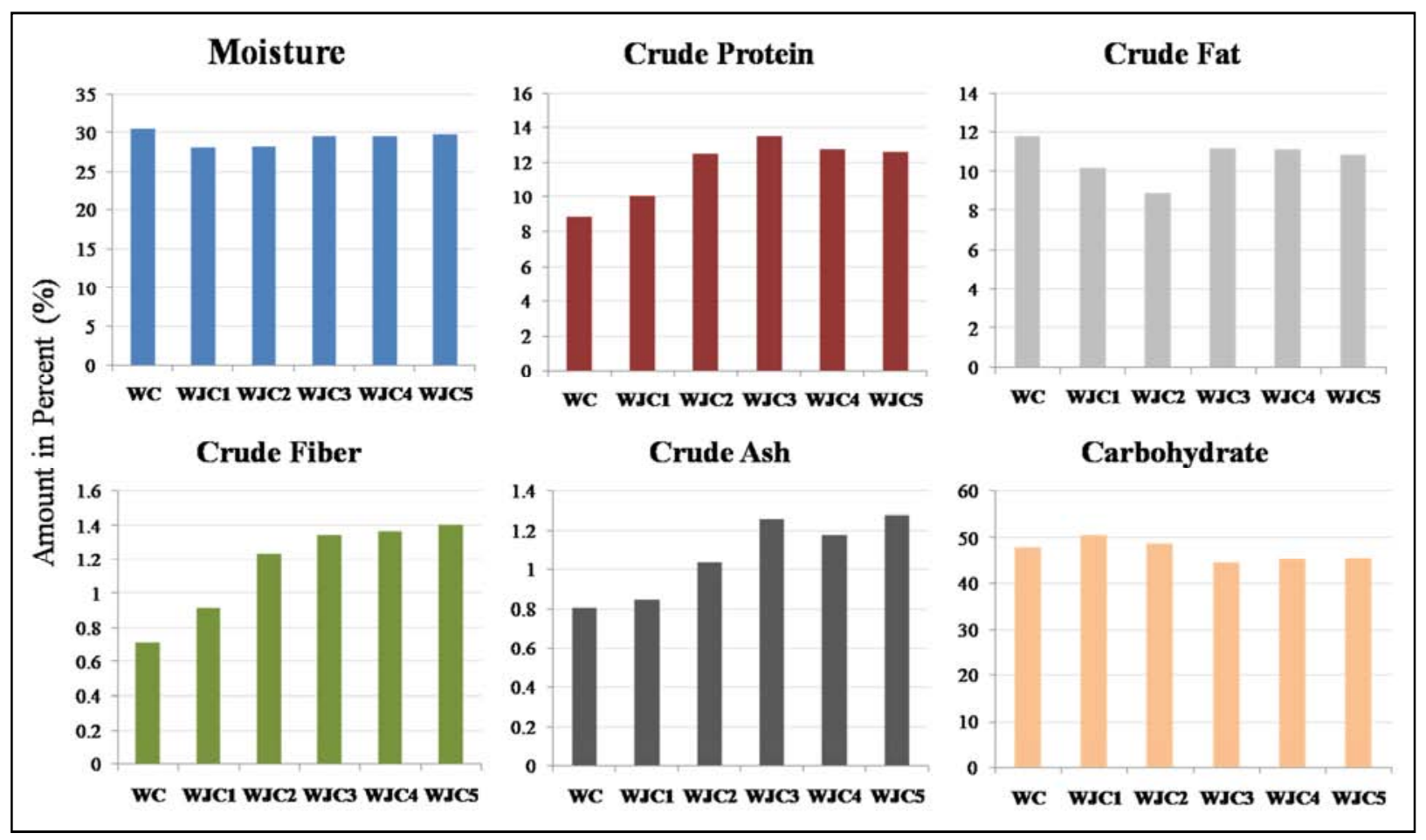

Figure 3. Proximate composition analysis of different blended cakes of wheat flour and jackfruit seed flour in percentage.

The crude fat of all the cakes were in range of $10-12 \%$. Although, the crude fiber content of cakes were least in amount $(<2 \%)$ but the figure implies that amount of fiber increases with increasing the percentage of JFS flour in the cakes. Similar result was found in case of crude ash which denotes the increasing amount of mineral content with addition of JFS flour. Carbohydrate contents were found
$48.08 \%, 50.72 \%, 48.83 \%, 44.57 \%, 45.39 \%$, and $45.46 \%$ for WC, WJC1, WJC2, WJC3, WJC4, and WJC5 respectively.

\subsection{Sensory Evaluation of Cake}

The sensory evaluation of blended cakes by 9 point hedonic rating is given in table- 6 and figure- 4 . 
Table 6. Sensory Evaluation of different blended cakes by 9 point hedonic rating.

\begin{tabular}{llllll}
\hline S1. No & Product code & Color & Taste & Aroma & Acceptability \\
\hline 01. & WC & $5.00 \pm 1.41$ & $5.00 \pm 1.41$ & $5.30 \pm 1.96$ & $6.10 \pm 0.75$ \\
02. & WJC1 & $4.80 \pm 1.16$ & $6.00 \pm 1.67$ & $5.50 \pm 1.64$ & $6.50 \pm 1.37$ \\
03. & WJC2 & $4.10 \pm 1.60$ & $6.60 \pm 1.21$ & $6.16 \pm 1.47$ & $7.00 \pm 1.26$ \\
04. & WJC3 & $6.60 \pm 1.50$ & $7.30 \pm 1.36$ & $6.33 \pm 1.21$ & $7.80 \pm 1.16$ \\
05. & WJC4 & $7.10 \pm 0.75$ & $5.10 \pm 1.16$ & $7.00 \pm 0.89$ & $5.33 \pm 0.81$ \\
06. & WJC5 & $7.50 \pm 1.37$ & $3.60 \pm 1.63$ & $7.33 \pm 0.51$ & $5.00 \pm 0.89$ \\
\hline
\end{tabular}

The results are expressed as mean $\pm \mathrm{SD}$ (Standard Deviation). The results showed that in terms of color WJC5 cake is more acceptable due to its dark color. But WJC3 got more acceptances in case of taste and overall acceptability, while aroma of WJC5 is higher than others because of its higher portion of jackfruit seed flour. But WJC5 achieved lesser acceptance in taste due to lack of smoothness. So, by comparing all the results WJC3 is more acceptable than other cakes.

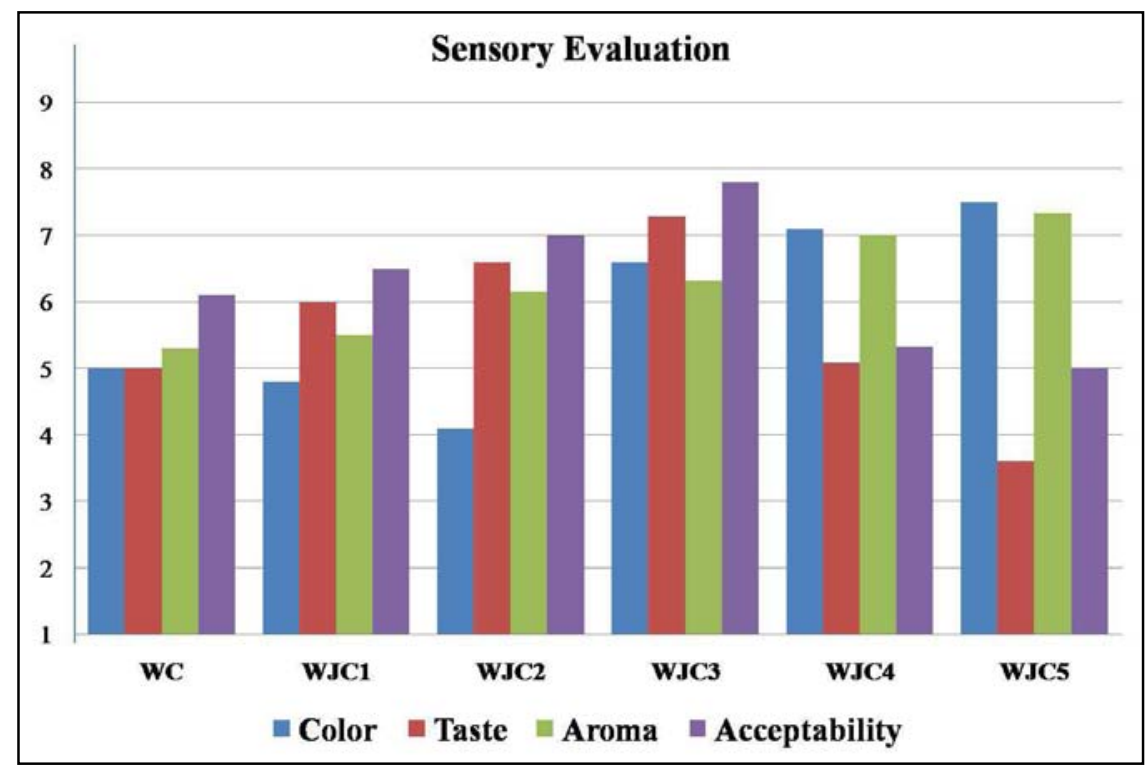

Figure 4. Sensory Evaluation of JFS flour and wheat flour blended cakes by 9 point hedonic rating.

In this study, out of six sets of cakes, WJC3 was not only the most protein enriched cake but it also contain other nutritional parameters in appreciable amount. Even on the basis of sensory evaluation $\mathrm{WJC} 3$ revealed the most acceptable cake by comparing with Cake WC, WJC1, WJC2, WJC4, and WJC5. So WJC3 is our desired protein enriched supplementary food with higher nutritional value. It is now important to assess its susceptibility towards microbial attack.

\subsection{Microbiological Analysis of WJC3 Cake}

It is most important that a food sample must have to be microbiologically stable and safe to eat. To ensure the stability and safety the cake WJC3 was analyzed microbiologically. Microbiological analysis results are shown in table-7. The results showed that this cake contains 5000 $\mathrm{cfu} / \mathrm{g}$ total viable count which is within the range for safety indication of bakery products $10,000 \mathrm{cfu} / \mathrm{g}$ [40]. The results for E. coli and Yeast \& Mould test for a cake is found nil for the cake sample. So, the cake prepared by blending wheat flour and jackfruit seed flour are microbiologically safe for human consumption in spite of no externally added preservatives used for its preparation.
Table 7. Microbiological Analysis of WJC3 Cake.

\begin{tabular}{ll}
\hline Microorganism & Amount \\
\hline Total Viable Count & $5000 \mathrm{cfu} / \mathrm{gm}$ \\
Coli form & $\mathrm{Nil} / \mathrm{gm}$ \\
Yeast \&Mould & $\mathrm{Nil} / \mathrm{gm}$ \\
\hline
\end{tabular}

\section{Conclusion}

The main focus of the present research was to utilize the JFS flour with higher nutritional worth to develop a protein enriched supplementary food. The nutritional composition was analyzed by the methods of Association of Official Analytical Chemists (AOAC). The JFS flour contains $42.49 \%$ carbohydrate and $16.01 \%$ crude protein along with other nutrients in appreciable amount. This significant amount of protein was isolated by alkaline extraction and isoelectric precipitation ( $\mathrm{pH}-1.63)$ technique. The amino acid profile revealed that the isolated JFS protein contain 13 amino acids. Lysine (10.30\%) and tyrosine (6.67\%) were present in highest amount out of 7 essential and 6 nonessential amino acids respectively. Jackfruit seed flour was utilized along with wheat flour at different proportion to 
prepare 6 sets of cakes whose nutritional compositions were also analyzed. Among six sets of cakes WJC3 (JFS flour, 25g: wheat flour, 25g) was found to contain the highest amount of protein and it was rated as the best cake in terms of sensory evaluation. This cake (WJC3) also showed a good response in microbial test which means that it is completely safe to eat without using any preservatives.

The results of this study will highly inspire people to utilize jackfruit seed flour in food preparation particularly in cake, a bakery product. Since cakesare consumed by all ages of people, so, one of the most convenient ways to utilize jackfruit seed flour is to prepare supplementary food like cake which can eventually minimize protein malnutrition among the people in a developing country like ours.

\section{Acknowledgements}

The authors are grateful to Ms. Shahana parveen, Principal Scientific Officer (PSO), Food Microbiology section, Institute of Food Science and Technology, Dr. Mahbubur Rahman, Senior Scientific Officer; Mr. Md. Mashiar Rahman, Senior Scientific Officer and Ms. Umme Fatema Shahajadee, Senior Scientific Officer, Food Enzymology section, Institute of Food Science and Technology, Bangladesh Council of Scientific and Industrial Research (BCSIR) for their helpful contribution in the Laboratory analyses.

\section{References}

[1] S. Jahan, T. Gosh, M. Begum, BK. Saha, Nutritional Profile of Some Tropical Fruits in Bangladesh: Specially Anti-Oxidant Vitamins and Minerals, Bangladesh J. Med. Sci., 2014; 10(2): 95-103.

[2] D. Sturrock, Fruits of Southern Florida, South Eastern Printing Co. Stuart. Fla, 1959; pp. 114

[3] HM. Samaddar, TK. Bose, SK. Mishra, Fruits of India: tropical and subtropical, India: NayaProkash, 1985, pp. 638649 .

[4] GS. Siddappa, Effect of processing on the trypsin inhibitor in jackfruit seed (Artocarpusintegrifolia). J SciInd Res., 1957; 166-199.

[5] Rahman, AKMM. Huq, E. Mian, A. Chesson, Microscopic and chemical changes occurring during the ripening of two forms jackfruit (ArtocarpusheterophyllusL), Food Chemistry, 1995; 52: 405-410.

[6] Y. Selvaraj, DK. Pal, Biochemical changes during ripening of jackfruit (ArtocarpusheterophyllusL), J Food SciTechnol, 1989; 26: 304-307.

[7] MS. Abedin, MM. Nuruddin, KU. Ahmed, A Hossain, Nutritive compositions of locally available jackfruit seeds (Artocarpusheterophyllus) in Bangladesh, Int J Biosci., 2012; 2(8): 1-7.

[8] FAO/WHO, Report of a Joint FAO/WHO Ad Hoc Expert Committee on Energyand Protein Requirements, Geneva: World Health Organization,1973, WHO Technical Report
Series No. 522.

[9] Nutrition Working Group of the International Olympic Committee, "Nutrition for athletes", IOC Consensus Conference on Nutrition for Sport, Lausanne, 2003.

[10] AR. Chowdhury, AK. Bhattacharyya, P. Chattopadhyay, Study on functional properties of raw and blended Jackfruit seed flour (a non-conventional source) for food application, Indian J Nat Prod Resour, 2012; 3(3): 347-353.

[11] KF. Mattil, Considerations for choosing the right plant proteins, Food Prod Develop., 1973; 7: 40-42.

[12] D. Gupta, S. Mann, A. Sood, RK. Gupta, Phytochemical, nutritional and antioxidant activity Evaluation of seeds of jackfruit (artocarpousheterolphyllusLam), Int. J. Pharma Bio Sci., 2011; 2(4): 336-345.

[13] HM. Burkill, The Useful Plants of West Tropical Africa, Kew: Royal Botanic Gardens, 1997, pp.160-161.

[14] SS. Nair, NC. Madembil, P. Nair, S. Raman, SB. Veerabadrappa, Comparative analysis of the antibacterial activity of some phytolectins, Int. Curr. Pharm. J., 2013; 2(2): 18-22.

[15] P. Chakraborty, DK. Bhattacharyya, NR. Bandyopadhyay, M. Ghosh, Study on Utilization of jackfruit seed flour and defatted soy flour mix in preparation of breakfast cereal by twin screw extrusion technology, Discovery, 2013;4(11): 32-37.

[16] KE. Ileleji, AA. Garcia, ARP. Kingsly, CL. Clementson. Comparison of standard moisture loss-on-drying methods for the determination of moisture content of corn distillers dried grains with solubles. J. AOAC Int., 2010; 93(3): 825-832.

[17] JM. Lynch, DM. Barban, Kjeldahl nitrogen analysis as a reference method for protein determination in dairy products. J AOAC International, 1999; 82(6): 1389-1401.

[18] NJ. Thiex, L. Novotny, A Crawford, Determination of Ash in animal feed: AOAC Official Method 942.05 Revisited. J AOAC International, 2012; 95(5): 1392-1397.

[19] M. Jrgen. Gravimetric determination of Acid Detergent Fiber and Lignin in feed: Interlaboratory study. J AOAC International, 2009; 92(1):74-90.

[20] NJ. Thiex, S. Anderson, B. Gildemeister. Crude fat, diethyl ether extraction, in feed, cereal grain, and forage (Randall/Soxtec/Submersion Method): Collaborative study. J AOAC International, 2003; 86(5): 888-898.

[21] EW. Menezes, AT. Melo, GH. Lima, FM. Lajolo, Measurement of carbohydrate components and their impact on energy value of foods. J. Food Comp. Anal., 2004; 17: 331338 .

[22] Dionex Corporation, Determination of hexavalent chromium in drinking water using ion chromatography. Application update 144; LPN 1495, 2003, Sunnyvale, CA.

[23] B. Zhang, Y. Cui, G. Yin, X. Li, X. Zhou, Alkaline Extraction Method of Cottonseed Protein Isolate, Mod Appl Sci., 2009; 3(3): 77-82.

[24] FAO, Report of an FAO Expert Consultation on Dietary protein quality Evaluation in human nutrition, Rome: Food and agriculture organization of the united nations, 2011, Series. 
[25] NJJ. Kalva, Comparison of the hedonic general labeled magnitude scale to the hedonic 9-point scale: A thesis presented to the graduate school of the university of florida in partial fulfillment of the requirements for the degree of master of science, University of Florida, 2009. o. 92.

[26] C. Vanderzant, DF. Splittstoesser, Compendium of Methods for the Microbiological Examination of foods, Washington D. C., 1992, pp. 75-87.

[27] VA. Arilington, Bacteriological Analytical Method, 6th edition, Washington, DC: Association of official Analytical Chemists for FDA, 1992, pp. 17-21.

[28] Microbiology-General Guidance for the enumeration of Microorganism-colony count technique at $35^{\circ} \mathrm{C}$ (first revision), India: Bureau of Indian Standard, 1991, IS5462.2002, ISO4833.

[29] C. Vanderzant, DF. Splittstoesser, Compendium of Methods for the Microbiological Examination of foods, Washington D. C., 1992, pp.239-249.

[30] VA. Arilington, Bacteriological Analytical Method, 6th Edition, Washington DC: Association of official Analytical Chemists for FDA, 1992, pp. 227-230.

[31] AOAC, Official Methods of Analysis of Association of Official Analytical Chemist, 16th Edition, Virginia. USA: AOAC, 1995, pp.4-5.

[32] C. Vanderzant, DF. Splittstoesser, Compendium of Methods for the Microbiological Examination of foods, Washington D. C., 1992, pp. 325-341.

[33] VA. Arilington, Bacteriological Analytical Method, 6th
Edition, Washington DC: Association of official Analytical Chemists for FDA, 1992, pp.27-31.

[34] HMA. Awal, S. Gheyasuddin, Biochemical parameters of jackfruit seed meal, Bangladesh J. Agril. Res., 1991; 16(1): 17-22.

[35] S. Kumar, AB. Singh, AB. Abidi, RG. Upadhyay, A. Singh, Proximate composition of jackfruit seeds, Journal of Food Science and Tech., 1988; 25(5): 308-309.

[36] MEG. Shills, VR. Young, Modern nutrition in health and disease. In: Nutrition (Ed. Neiman, D. C., Buthepodorth, D. E. and Nieman, C. N.), Dubugue, USA: WmC. Brown publishers, 1988, pp. 276-282.

[37] FO. Bobbio, AA. El-Dash, PA. Bobbio, LR. Rodrigues, Isolation and characterization of the physicochemical properties of starch of jackfruit seeds (Artocarpusheterophyllus), Cereal Chem, 1978; 55:505-511.

[38] S. Airani, Nutritional quality and value addition to jack fruit seed flour, a thesis submitted to the University of Agricultural Sciences, Dharwad in partial fulfillment of the requirements for the degree of Master of Home Science in Food Science and Nutrition, University of Agricultural Sciences, Dharwad 580005, 2007.

[39] R. Marnoch, LL. Diosady, Production of Mustard Protein Isolates from Oriental Mustard Seed (Brassica juncea L.), JAOCS, 2006; 83(1): 65-69.

[40] CR. Elevitch, HI. Manner, Artocarpusheterophyllus (jackfruit), Species Profiles for Pacific Island Agro Forestry, 2006; 1(1):1-16. 